\title{
DAYA PREDIKSI HASIL UJI KOMPETENSI \\ SISWA SEKOLAH MENENGAH KEJURUAN BIDANG KEAHLIAN \\ TEKNIK BANGUNAN
}

Danny Meirawan

FPTK Universitas Pendidikan Indonesia Bandung (email: dmeirawan@upi.edu)

\begin{abstract}
Abstrak: Daya Prediksi Hasil Uji Kompetensi Siswa Sekolah Menengah Kejuruan Bidang Keahlian Teknik Bangunan. Penelitian ini bertujuan untuk memaparkan daya prediksi hasil uji kompetensi siswa SMK Bidang Keahlian Teknik Bangunan Program Keahlian Gambar Bangunan terhadap kesempatan kerja di bidang konstruksi bangunan. Metode penelitian menggunakan penelitian deskriptif analitik. Populasi penelitian adalah siswa pada SMK Negeri di Kota Bandung Bidang Keahlian Teknik Bangunan Program Keahlian Gambar Bangunan, sedangkan sampel adalah siswa SMK sebanyak 90 orang siswa. Data hasil uji kompetensi diperoleh dengan metode dokumentasi, sedangkan data tentang kesempatan kerja di bidang konstruksi bangunan diperoleh dengan angket. Hasil penelitian adalah sebagai berikut. (1) Gambaran umum hasil uji kompetensi siswa SMK Bandung Bidang Keahlian Teknik Bangunan Program Keahlian Gambar Bangunan sebesar 70\% berada pada kategori baik. (2) Kesesuaian kompetensi yang diujikan dengan tugas pekerjaan di bidang konstruksi bangunan termasuk kategori baik. (3) Daya prediksi didasarkan pada besarnya sumbangan yang diberikan oleh hasil uji kompetensi dalam merebut kesempatan kerja di bidang konstruksi bangunan sebesar 20,1\%. Dengan uji kompetensi diharapkan siswa dapat memunyai kompetensi yang sesuai dengan dunia kerja sehingga memunyai kesempatan kerja yang lebih besar.
\end{abstract}

Kata Kunci: daya prediksi, kesempatan kerja, uji kompetensi

\begin{abstract}
The Predictive ability of the Competency Test Results of Construction Engineering Department Students at Vocational High School. This study aims at describing the predictive ability (predictability) of the competency test results of vocational high school students of Building Drawing Study program at Construction Engineering Department towards the job opportunity in the field of building construction. The research method used was analytical description. The population in this research was all students of Building Drawing Study program at Construction Engineering Department of Vocational High Schools in Bandung, while the samples were 90 students of vocational High School majoring Drawing Building study Program. The data of competency test results were collected by document study, and the data of jobs opportunity in the field of Building construction were collected by questionnaire. The results of this study are as follows: (1) General description of competency test result of vocational high schools
\end{abstract}


students of Building Drawing study program in Construction Engineering Department shows that $70 \%$ of them is categorized as good. (2) The appropriateness of the tested competencies with the jobs in the field of building construction are categorized "good".(3) The predictive ability based on the contributions resulted from the competence test to get the jobs in the field of building construction is $20,1 \%$. Conclusion of this research is through the competency tests students are expected to have the appropriate competencies with the work field so that the opportunity to get job is bigger.

Keywords: predictive ability (predictability), jobs opportunity, competence test

\section{PENDAHULUAN}

Salahsatu persoalan yang dihadapi umumnya oleh lembaga-lembaga pendidikan tinggi maupun pendidikan menengah bidang kejuruan sebagaimana yang dihadapi oleh Sekolah Menengah Kejuruan (SMK), bukan saja menyangkut output tetapi juga outcomes pendidikan. Mengadopsi Harrel (1996) dalam Morley (2001), output pendidikan, merupakan hasil langsung dari suatu pelaksanaan internal program dan proses pendidikan dengan ukuran kuantitatif, seperti jumlah lulusan, nilai rata-rata IPK, nilai UN dan US, jumlah siswa yang lolos standar uji kompetensi, lama masa studi, jumlah siswa yang melanjutkan ke jenjang pendidikan tinggi, lama waktu sebelum memperoleh pekerjaan, dan lain-lain. Outcomes pendidikan, adalah produk dari program dan proses pendidikan yang lebih bermakna kualitatif, yaitu bagaimana lulusan itu bermanfaat dan dapat menciptakan perubahan baik bagi dirinya sendiri maupun masyarakat secara umum. Sebagai misal, outcomes ini menyangkut pekerjaan, karir, penghasilan, dan kesejahteraan individu lulusan, serta kontribusinya bagi peningkatan kesejahteraan keluarga, masyarakat, dan lingkungannya.

Selama ini, orientasi dan kriteria mutu, efektifitas dan efisiensi pendidikan, serta relevansi pendidikan masih terbatas pada persoalan output. Sekarang, terlebih lagi terkait dengan rencana peningkatan proporsi jumlah siswa SMK yang diharapkan berkelanjutan secara konsisten, persoalan outcomes menjadi salahsatu faktor yang krusial.

Masyarakat, khususnya masyarakat (orangtua siswa) kalangan menengahbawah yang menjadi sebagian besar pangsa pasar SMK, lebih sensitif terhadap persoalan outcomes dari pada output, dibandingkan dengan orangtua siswa SMA. Oleh sebab itu, tantangan besar yang merupakan implikasi dari peningkatan jumlah siswa SMK supaya berkelanjutan, adalah bagaimana SMK dapat mengembangkan faktor outcomes ini.

Sekaitan dengan outcomes SMK, kenyataan itu disebabkan oleh beberapa hal. Pertama, beragamnya spektrum keahlian yang dibutuhkan pasar kerja, yang belum dapat dipenuhi oleh rumpun keahlian di SMK. Kedua, mutu 
lulusan SMK belum sesuai dengan harapan dan persyaratan dunia Industri. Ketiga, pasar kerja sendiri belum bertumbuh secara signifikan akibat masih belum berkembangnya sektor riil.

Persoalannya, perbaikan beberapa indikator makroekonomi ternyata belum diikuti oleh terbukanya kesempatan kerja yang lebih baik, terutama di sektor formal. Hal ini terlihat dari masih tingginya tingkat pengangguran dan besarnya jumlah pekerja di sektor informal yang relatif berpenghasilan rendah dibandingkan sektor formal. Padahal, pertumbuhan ekonomi tidak akan memberikan manfaat bagi kesejahteraan tanpa adanya kontribusi yang riil terhadap kesempatan kerja. Dari segi mikro, dilihat dari sudut pandang pendidikan dan ketenagakerjaan, jumlah pengangguran itu menunjukkan terjadinya kesenjangan yang lebar antara jumlah, jenis, dan kualifikasi keahlian yang tersedia dengan kebutuhan pasar kerja.

Sementara itu, lulusan SMK dengan jumlah lulusan yang jauh lebih sedikit dari SMA, juga tidak sepenuhnya tertampung dalam dunia kerja. Kenyataan ini disebabkan oleh beberapa hal. Pertama, beragamnya spektrum keahlian yang dibutuhkan pasar kerja, yang belum dapat dipenuhi oleh rumpun keahlian di SMK. Kedua, mutu lulusan SMK belum sesuai dengan harapan dan persyaratan dunia industri. Ketiga, pasar kerja sendiri belum bertumbuh secara signifikan akibat masih belum berkembangnya sektor riil.

Fakta lain yang terjadi saat ini dan melanda bangsa Indonesia adalah banyaknya pengangguran yang diprediksi salah satu penyebabnya adalah lembaga pendidikan menghasilkan lulusan yang tidak siap kerja. Untuk memecahkan persoalan di atas maka kita perlu mengambil langkah-langkah yang konkret dan komprehensif guna menghasilkan lulusan yang siap pakai, kompetitif dan mempunyai nilai jual tinggi sehingga dapat bersaing di era global. Salah satu langkah penting tersebut selain peningkatan dukungan pemerintah harus pula diimbangi adanya pelibatan unsur dunia usaha-dunia industri (DU-DI) terkait, diantaranya dalam pemecahan masalah dalam pengelolaan sekolah menengah kejuruan (SMK), khususnya dalam pemberian sertfikasi keahlian pada lulusannya.

Dalam bidang pendidikan kejuruan, salah satu hal yang masih menjadi keprihatinan adalah kemampuan sekolah menengah kejuruan dalam menghasilkan lulusan yang siap kerja. Beberapa tahun yang lalu, Departemen Pendidikan Nasional telah menggariskan kebijakan "Link and Match" (Keterkaitan dan Kesepadanan) dalam meningkatkan relevansi program pendidikan yang relevan dengan tuntutan dan perkembangan dunia kerja dilatorbelakangi oleh kemajuan masyarakat dan dunia kerja yang sangat cepat, sebagai akibat dari kecepatan laju perkembangan ilmu dan teknologi.

Salah satu upaya untuk meningkatkan mutu dan relevansi pendidikan kejuruan adalah peningkatan keterkaitandan kesepadanan (link and match) dalam implementainya diwujudkan dalam suatu model yang disebut Pendidikan Sistem Ganda (PSG). 
Pendidikan Sistem Ganda adalah "suatu bentuk penyelenggaraan pendidikan kejuruan, yang memadukan secara sistematik dan sinkron program pendidikan di sekolah dan program penguasaan keahlian melalui kegiatan bekerja langsung di dunia kerja/dunia industri yang relevan, terarah untuk mencapai penguasaan kemampuan keahlian profesional tertentu" (Depdiknas MPKN, 1996:7).

Dalam pengertian tersebut, tersirat ada dua pihak yang terlibat dalam pengelolaan pendidikan kejuruan tersebut, yaitu: lembaga pendidikan pelatihan/sekolah (SMK) dan Lapangan Kerja (Dunia Usaha-Dunia Industri) yang secara bersama-sama menyelenggarakan suatu program dan pelatihan kejuruan. Kedua belah pihak secara sungguh-sungguh terlibat dan bertanggung jawab langsung mulai dari tahap perencanaan program, tahap penyelenggaraan, sampai pada tahap penilaian dan penentuan kelulusan peserta didik, serta upaya pemasaran tamatannya.

Paradigma pengelolaan pendidikan berbasis sekolah, ke pola pendidikan berbasis ganda sesuai dengan kebijakan link and match, mengharapkan supaya program pendidikan kejuruan itu dilaksanakan di dua tempat. Sebagian program pendidikan dilaksanakan di sekolah, yaitu teori dan praktek dasar kejuruan, dan sebagian lainnya dilaksanakan di dunia kerja, yaitu keterampilan produktif yang diperoleh melalui prinsip learning by doing. Sejalan dengan pendapat tersebut, Meirawan (1996:192) mengungkapkan bahwa, "Pendidikan yang dilakukan melalui proses bekerja di dunia kerja yang utama adalah akan membentuk sikap dan etos kerja selain akan memberikan pengetahuan, keterampilan dan nilainilai dunia kerja".

Sumber daya manusia berkualitas yang memiliki kemampuan dan etos kerja tinggi, sangat diperlukan agar mampu berperan aktif dalam mengisi pembangunan dan mampu berkompetiti untuk merebut kesempatan kerja yang dewasa ini semakin ketat. Natanegara (Supratman, 1996) mengemukakan bahwa hampir semua lapangan pekerjaan menuntut sumber daya manusia yang terampil dalam bidang kerja yang digelutinya.

Sekolah Menengah Kejuruan (SMK) sebagai bentuk satuan pendidikan kejuruan mempunyai tujuan mempersiapkan peserta didik terutama untuk bekerja dalam bidang tertentu. Sekolah Menengah Kejuruan adalah jenjang pendidikan menengah formal yang kurikulumnya mengacu pada pendekatan akan kebutuhan dunia usaha atau industri. Salah satu tujuan SMK Program Keahlian Gambar Bangunan yaitu menjadi tenaga kerja menengah untuk mengisi kebutuhan dunia usaha dan industri pada saat ini maupun masa yang akan datang dalam lingkup keahlian Teknik Bangunan, khususnya Teknik Gambar Bangunan. Sesuai dengan tujuan SMK Program Keahlian Gambar Bangunan tersebut, maka siswa diharapkan dapat mengembangkan pengetahuan yang telah dipelajari di Sekolah pada dunia usaha atau industri.

Keterkaitan antara pendidikan untuk meningkatkan kesempatan kerja 
tidak dapat dipisahkan satu sama lain. Dalam menyiapkan siswa untuk bekerja pun, diperlukan pendidikan yang bersandar pada teknologi dan kompetensi. Hal ini dapat dibuktikan dari setiap lulusan yang siap bekerja harus memiliki kompetensi yang dapat menunjang karirnya dalam bekerja, bila tidak demikian maka akan sulit dalam memperoleh kesempatan kerja.

Pengukuran kemampuan siswa SMK Program Keahlian Gambar Bangunan melalui uji kompetensi merupakan suatu bentuk evaluasi hasil belajar, yang melibatkan dan dilakukan oleh pihak pemakai tamatan dan lembaga-lembaga profesi. Uji kompetensi dilaksanakan sebagai strategi untuk memperoleh tamatan yang dipersyaratkan oleh lapangan kerja. Sekolah bersama siswa berupaya agar tamatan sekolah kejuruan ini mampu bersaing di dunia usaha atau industri. Uji kompetensi sebagai bentuk pengukuran terhadap kemampuan yang dimiliki siswa, dapat memberikan bukti bahwa siswa mampu melaksanakan tugas sesuai standar dan tuntutan lapangan pekerjaan. Persepsi siswa pada saat uji kompetensi dapat digunakan untuk mengantisipasi tingginya tingkat persaingan dalam memperoleh kesempatan kerja di bidang konstruksi bangunan.

Tujuan penelitian ini adalah untuk mengetahui (1) gambaran umum hasil uji kompetensi siswa SMK bidang keahlian teknik bangunan pogram keahlian gambar bangunan; (2) kesesuaian kompetensi dengan kesempatan kerja di bidang konstruksi bangunan; dan (3) daya prediksi hasil uji kom- petensi siswa SMK bidang keahlian Teknik Bangunan program keahlian Gambar Bangunan terhadap kesempatan kerja di bidang konstruksi bangunan.

Salah satu program yang dilaksanakan sebagai upaya peningkatan mutu tamatan Sekolah Menengah Kejuruan (SMK) adalah uji kompetensi SMK. Melalui uji kompetensi akan diperoleh gambaran tentang mutu hasil pendidikan nasional secara berkelanjutan (Depdikbud, 1999). Uji kompetensi dilaksanakan untuk memperoleh gambaran tentang kemampuan produktif individu siswa sesuai dengan kompetensi tamatan sebagaimana yang dipersyaratkan pada profil kemampuan tamatan SMK. Hal ini sejalan dengan pendapat Bunk (1994:13) yang menyatakan bahwa lingkup kompetensi (profesional) meliputi (1) kompetensi didasarkan pada analisi peran dan tanggung jawab professional; (2) kompetensi menjelaskan hasil belajar yang diperlihatkan pada kinerja (performance); (3) aspek kompetensi menjelaskan criteria penilaian; (4) penguasan kompetensi merupakan prediktor dan juga validasi yang efektif tentang jabatan profesional yang akan di dilaksanakannya.

Maksud dari pelaksanaan uji kompetensi yang dilakukan pada SMK adalah untuk mendapatkan pengakuan atau legalitas dan kepercayaan dari pihak dunia industri sebagai konsumen/pemakai bagi para siswa atau tamatan telah dinyatakan lulus berhasil dalam mengikuti uji kompetensi dan mendapatkan serifikat. Sementara itu, yang menjadi tujuan dari pelaksaan uji 
kompetensi itu sendiri adalah untuk mencetak disiplin dan sikap kerja serta hasil kerja sesuai dengan tuntutan dan kebutuhan dunia industri.

Setiap individu mempunyai wawasan tersendiri tentang kesempatan kerja baik menyangkut jenis pekerjaan ataupun cara memasukinya. Sempitnya tentang wawasan kesempatan kerja, pada dasarnya bukan semata-mata hanya disebabkan oleh ketidaktahuan, bagaimana cara memperoleh pekerjaan, dan jenis pekerjaan apa saja yang perlu dipahami dalam pekerjaan.

Terdapat 2 aspek pokok yang harus dipahami tentang kesempatan kerja, yaitu karakteristik pribadi atau pengetahuan diri dan karakteistik pekerjaan itu sendiri. Aspek pengetahuan diri meliputi, pengetahuan seseorang terhadap aspek bakat atau kemampuan, minat dan cita-cita. Analisis yang dimulai dari diri sendiri sangat diperlukan untuk mempersiapkan diri sebaikbaiknya sebelum memasuki lapangan pekerjaan.

Setiap siswa SMK setelah menyelesaikan pendidikannya, dihadapkan pada tuntutan hidup selanjutnya yaitu memasuki lapangan pekerjaan. Masalah pekerjaan sebenarnya bukan suatu hal yang aneh bagi siswa SMK, hal ini disebabkan oleh sifat dan tuntutan disekolah tersebut. Dengan demikian mereka pada dasarnya telah siap untuk memasuki lapangan pekerjaan.

Kecenderungan yang ada sekarang ini, setidaknya menjadi bahan pertimbangan dalam memasuki lapangan pekerjaan. Kecenderungan tersebut berkenaan dengan perubahan sistem pekerjaan sebagai contoh dengan adanya kemajuan teknologi tenaga manusia mulai dikurangi dan diganti dengan mesin. Masalah ini jika dihubungkan dengan banyaknya lulusan di sekolah lanjutan maka dapat dipastikan akan terjadinya suatu sistem kompetensi dalam memperoleh pekerjaan.

SMK sebagai salah satu lembaga pendidikan yang menghasilkan tenaga kerja teknisi tingkat menengah, dituntut untuk menghasilkan lulusan yang siap kerja, sesuai dengan bidang keahlian atau memiliki profesionalisme. Setiap lulusan SMK Program Keahlian Gambar Bangunan mempunyai kesempatan kerja untuk bekerja diperusahaan jasa kontraktor, konsultan pengawas dan instansi pemerintah. Jabatan tamatan program keahlian gambar bangunan adalah juru gambar bangunan, dengan lingkup pekerjaan; (1) gambar bangunan gedung; (2) gambar jalan dan jembatan; dan (3) gambar bangunan air

\section{METODE}

Penelitian untuk mengungkapkan daya prediksi hasil uji kompetensi terhadap kesempatan kerja di bidang konstruksi bangunan ini menggunakan metode deskriptif. Populasi dalam penelitian ini adalah siswa SMK Negeri (SMKN 5 dan SMKN 6) di kota Bandung yang membina bidang Keahlian Teknik Bangunan pada Program Keahlian Gambar Bangunan. Jumlah siswa yang ada di SMKN tersebut berjumlah 120 siswa, sedangkan sampel dipilih secara acak sebanyak 90 siswa.

Teknik pengumpulan data yang dipergunakan dalam penelitian ini adalah: (1) teknik angket atau kuesioner 
adalah teknik komunikasi tidak langsung sebagai alat pengumpul data untuk memperoleh data mengenai kesempatan kerja siswa SMK Bidang Keahlian gambar Bangunan; (2) teknik dokumentasi digunakan dalam pengumpulan data untuk variabel Hasil Uji Kompetensi $(\mathrm{X})$, data yang dikumpulkan melalui dokumen, yaitu hasil uji kompetensi siswa SMK Program Keahlian Gambar Bangunan. Teknik ini juga diterapkan untuk memperoleh beberapa informasi berkaitan dengan pelaksanaan uji kompetensi.

Teknik analisis data yang digunakan adalah analisis korelasi dan regresi. Analisis korelasi dilanjutkan untuk mendapatkan koefisien determinasi. Pengujian koefisien determinasi atau koefisien penentu dan persamaan regresi untuk mengetahui besarnya pengaruh variabel hasil uji kompetensi terhadap variabel kesempatan kerja (Sudjana, 2002). Hal ini dapat menunjukkan daya prediksi variabel hasil uji kompetensi terhadap variabel kesempatan kerja.

\section{HASIL}

Uji kompetensi adalah suatu proses pengumpulan data untuk mengukur penguasaan kompetensi siswa pada komponen produktif meliputi aspek kognitif, psikomotorik, dan afektif sesuai dengan bidang dan program keahlian (Depdikbud, 1999). Atas saran dan masukan dari berbagai pihak yang berkepentingan maka dilakukan penyempurnaan uji kompetensi. Penyempurnaan tersebut tidak saja dilakukan pada formulasi soal ujian, tetapi juga pada sistem pengujiannya, dan dikemas dalam bentuk pengujian kompetensi produktif.

Sistem pengujian kompetensi produktif dimaksudkan tidak saja dilakukan oleh unsur internal (sekolah) melainkan melibatkan secara aktif unsur eksternal (Parasuraman, 1990) khususnya dunia usaha/dunia industri baik sebagai asesor maupun sebagai verifier. Pada sisi lain sistem ini diharapkan dapat mendorong Dunia Industri/ Dunia Usaha untuk berperan sebagai Quality Assurance (QA) dan Quality Control(QC) dalam proses pendidikan kejuruan.

Pemberlakuan pengujian kompetensi produktif dalam uji kompetensi merupakan program strategis bagi pendidikan menengah kejuruan agar kualitas tamatan yang memiliki kemampuan sesuai dengan standar nasional/internasional dapat dicapai. Proses pengujian uji kompetensi produktif ini sekaligus menjadi wahana bagi dunia usaha dan industri dalam memberikan pengukuran terhadap kompetensi yang dimiliki tamatan SMK dalam bentuk sertifikasi kompetensi.

Gambaran umum hasil uji kompetensi secara rinci tertera pada Tabel 1. 
Tabel 1. Gambaran Hasil Uji Kompetensi Siswa SMK Bidang Keahlian Teknik Bangunan

\begin{tabular}{|c|c|c|c|}
\hline Kategori & Rentang & $\mathbf{F}$ & Prosentase $(\%)$ \\
\hline Sangat baik & $\mathrm{n}>7,505$ & 24 & 26,67 \\
\hline Baik & $5,835<n<7,505$ & 63 & 70,00 \\
\hline Cukup baik & $4,165<\mathrm{n}<5,835$ & 3 & 3,33 \\
\hline Kurang baik & $2,495<n<4,165$ & 0 & 0 \\
\hline Tidak Baik (Jelek) & $\mathrm{n}<2,495$ & 0 & 0 \\
\hline \multicolumn{2}{|c|}{ Jumlah } & 90 & 100 \\
\hline
\end{tabular}

Berdasarkan data yang tertera pada Tabel 1, sebagian besar (70\%) hasil uji kompetensi siswa SMKN (SMKN5 dan SMKN 6) di Bandung Bidang Keahlian Teknik Bangunan tergolong pada kategori baik, 26,67\% tergolong kategori sangat baik, dan 3,33\% tergolong cukup baik. Hasil ini menunjukkan bahwa secara umum hasil uji kompetensi sudah tergolong baik.

Dari penelitian ini menunjukan bahwa hasil uji kompetensi siswa SMKN Program Keahlian Gambar Bangunan di Kota Bandung, bila dilihat dari gambaran umum berada pada kategori baik, hal ini dapat diartikan bahwa penguasaan kompetensi produktif yang dimiliki oleh siswa tersebut juga baik, sehingga dapat dinyatakan bisa melaksanakan tugas atau pekerjaan tertentu berdasarkan ketentuan atau standar yang berlaku di lapangan kerja.

Penguasaan kompetensi yang diakui oleh dunia kerja dapat dilakukan mulai dari penyusunan kurikulum yang melibatkan unsur lapangan kerja, penyusunan dan pengembangan kurikulum dalam pendidikan kejuruan menurut Finch dan Crunkilton . (1979) harus melibatkan pihak luar yang akan menggunakan lulusan dari lembaga pendidikan kejuruan. Penyusunan program secara bersama dapat dilakukan seperti menyusun standar nasional pendidikan (PP No. 19 Tahun 2005). Demikian pula halnya dalam menyusun standar nasional pendidikan pada SMK, khususnya standar kompetensi lulusan bagi lulusan SMK yang melibatkan unsur sekolah dan unsure dunia kerja secara terintegrasi. Hal ini sejalan dengan apa yang dikemukan oleh Balley (1977), bahwa dalam menyusun standard yang berorietasi keterampilan dan berhubungan dengan pekerjaan tertentu harus mengintegrasikan antara tuntutan akademik dan tuntutan industri.

Demikian juga dengan pembelajaran, Descy Tessaring M. (2001), mengungkapkanbahwa pembelajaran harus dirancang sedemikian rupa sehingga sisw mendapatkan pengalaman yang terintegrasi antara apa yang diajarkan di sekolah dengan apa yang dilakukan di tempat kerja, hal itu telah dilakukan di SMK dengan program prakerin.

Untuk menghasilkan uji kompetensi yang baik, dapat dilakukan cara sebagai berikut seperti: memilih strategi pembelajaran yang sesuai dengan kebutuhan siswa dan karakteristik pembelajaran, sistem pengujian dikemas 
dalam bentuk kompetensi produktif, menumbuhkan motivasi pada siswa agar memperoleh hasil uji kompetensi yang baik, serta menumbuhkan persepsi yang positif tentang pelaksanaan uji kompetensi. Untuk mendapatkan strategi pembelajaran yang akan membentuk kompetensi produktif tersebut dapat dimulai dari penyusunan program pembelajaran yang bermakna, Dougherty dan Ellibee (1995), menyatakan bahwa untuk bermakna tersebut, program harus berorientasi pada dunia kerja (school to-work currilla).

Hal ini sejalan dengan pendapat yang dikemukan oleh Butler (1979) dan Bunk (1994), Calhoun dan Finch (1982) bahwa perekayasaan ruangan kelas atau tempat belajar yang menyediakan setiap siswa untuk mendapatkan pengalaman praktis yang authentik merupakan kunci dalam penyelenggaran program vokasi.

Selain itu, dalam pencapaian kompetensi produktif, diperlukan strategi pembelajaran yang melibatkan siswa baik dalam kegiatan belajar baik di sekolah, di masyarakat ataupun di dalam setting dunia pekerjaan; baik dengan pengalaman belajar melalui strategi problem solving, cara berkomunikasi ataupun melalui strategi penalaran. Dalam hal ini, Stasz, dkk. (1992) berpendapat bahwa situated learning dapat meningkatkan keterlibatan siswa dalam belajar.

Pelaksanaan Uji Kompetensi diharapkan dapat memberikan nilai tambah bagi tamatan dalam bentuk perolehan Seritifikat Kompetensi yang ditanda tangani oleh dunia UsahaDunia Industri. Untuk menjaga kualitas dan kewibawaan Sertifikat Kompetensi, maka hanya akan diberikan kepada siswa yang berhasil memenuhi persyaratan Penilaian Acuan Patokan (PAP) eksternal (DU/DI). Oleh sebab itu dilakukan verifikasi terhadap hasilhasil Uji Kompetensi komponen produktif oleh pihak eksternal (DU/DI) yang menetapkan layak tidaknya siswa tertentu mendapatkan Sertifikat Kompetensi.

Pihak eksternal diharapkan dapat bertindak sebagai penjamin mutu, sehingga Sertifikat Kompetensi yang diterbitkan benar-benar mendapatkan pengakuan dari pihak pengguna tamatan/apangan kerja. Bagi siswa yang dinyatakan lulus dalam verifikasi akan mendapatkan Sertifikat Kompetensi, sesuai dengan ketentuan tentang penerbitan Sertifikat Kompetensi.

Sertifikat Kompetensi merupakan surat berharga yang menyatakan tentang pengakuan dan penghargaan atas penguasaan kompetensi kepada seseorang setelah melalui proses pengujian atau evaluasi. Proses pengujian dan evaluasi yang dimaksud disini adalah melalui proses Uji Kompetensi, berdasarkan standar DU/DI. Unsur DU DI bertindak sebagai penjamin mutu, sehingga Sertifikat Kompetensi yang diterbitkan benar-benar mendapatkan pengakuan dari pihak pengguna tamatan/apangan kerja. Unsur eksternal adalah orang yang memiliki keahlian dibidangnya yang dapat berasal dari DU/DI, BLK, Pendidikan Tinggi, Asosiasi Profesi, maupun pihak-pihak lain dari unsur eksternal yang relevan.

Kesempatan kerja memiliki pengertian kompleks, didalamnya terdiri dari 
berbagai aspek yang saling berkaitan. Kesempatan kerja dapat diartikan sebagi peluang kerja, yaitu besarnya kesediaan perusahaan atau industri untuk memperkerjakan tenaga kerja yang diperlukan dalam proses produksi dan dukur dalam jumlah orang. Sugiono (1982) dalam Danny Meirawan (1996) mengemukan pengertian kesempatan kerja adalah "kesempatan dan tersedia- nya jenis-jenis pekerjaan atau jabatan dalam masyarakat berdasarkan pengetahuan kemampuan serta keterampilan yang dimiliki oleh seorang tenaga kerja".

Gambaran umum Kesempatan Kera di Bidang Konstruksi Bangunan bagi siswa SMK Bidang Keahlian Teknik Bangunan tertera pada Tabel 2.

Tabel 2. Gambaran Kesempatan Kerja di Bidang Konstruksi Bangunan

\begin{tabular}{|c|c|c|c|}
\hline Kategori & Rentang & $\mathrm{F}$ & Presentase (\%) \\
\hline Sangat baik & $\mathrm{n}>112,5$ & 78 & 86,67 \\
\hline Baik & $87,5<\mathrm{n}<112,5$ & 12 & 13,33 \\
\hline Cukup baik & $62,5<\mathrm{n}<87,5$ & 0 & 0,00 \\
\hline Kurang baik & $37,5<n<62,5$ & 0 & 0,00 \\
\hline Tidak Baik (Jelek) & $\mathrm{n}<37,5$ & 0 & 0,00 \\
\hline \multicolumn{2}{|c|}{ Jumlah } & 90 & 100 \\
\hline
\end{tabular}

Berdasarkan data yang tertera pada Tabel 2, Kesempatan Kerja di Bidang Konstruksi Bangunan bagi siswa SMKN di Bandung Bidang Keahlian Teknik Bangunan menurut sebagian besar $(86,67 \%)$ responden sangat baik dan sebagian kecil (13,33\%) siswa menyatakan kesempatan kerja tergolong baik. Jadi, menurut pandangan siswa kesempatan kerja lulusan program keahlian gambar bangunan untuk bekerja pada bidang konstruksi termasuk pada kategori sangat baik, mereka nantinya berharap akan mudah mendapatkan pekerjaan bidang konstruksi bangunan.

Untuk meningkatkan kesempatan kerja di bidang konstruksi bangunan di kalangan siswa SMK Program Keahlian Gambar Bangunan salah satunya adalah dengan penyempurnaan kurikulum yang benar-benar sesuai dengan tuntutan dunia kerja, khususnya kuri- kulum SMK program keahlian Gambar Bangunan yang bertugas dalam menyiapkan tenaga kerja terampil tingkat menengah untuk mengisi kesempatan kerja yang di bidang konstruksi bangunan, penajaman program keahlian, dan peningkatan hasil uji kompetensi. Robinson (1964), menegaskan bahwa untuk dapat mengisi kesempatan kerja harus dapat terisi oleh calon tenaga kerja yang memiliki kesesuaian dengan lapangan kerja.

Untuk mengetahui besarnya derajat hubungan antara variabel hasil uji kompetensi siswa SMK Bidang Keahlian Teknik Bangunan dan variabel kesempatan kerja di bidang konstruksi bangunan maka perlu dihitung nilai koefisien korelasi. Kedua variabel berdistribusi normal sehingga digunakan rumus koefisien korelasi dari product momen. Hasil dari perhitungan koefisien 
korelasi diperoleh sebesar 0,448. Hal ini berarti bahwa korelasi antara variabel hasil uji kompetensi siswa SMK Bidang Keahlian Teknik Bangunan dengan variabel kesempatan kerja di bidang konstruksi bangunan berkorelasi positif dan cukup berarti (berada pada daerah $0,41-0,60)$, sehingga dapat dinyatakan bahwa hasil uji kompetensi siswa SMK Bidang Keahlian Teknik Bangunan mempunyai hubungan yang cukup berarti dengan kesempatan kerja di bidang konstruksi bangunan.

Dari hasil penelitian, menunjukkan bahwa derajat hubungan antara hasil uji kompetensi siswa SMK Program Keahlian Gambar Bangunan terhadap kesempatan kerja di bidang konstruksi bangunan memiliki hubungan yang positif dan berarti dengan tingkat korelasi cukup.

Hasil perhitungan koefisien determinasi sebesar 20,07\%, dapat disimpulkan bahwa variabel hasil uji kompetensi memberikan sumbangan sebesar $20,07 \%$ terhadap variabel kesempatan kerja di bidang konstruksi bangunan atau dapat dengan kata lain bahwa sumbangan yang diberikan hasil uji kompetensi siswa SMK Bidang Keahlian Teknik Bangunan Program Keahlian Gambar Bangunan terhadap kesempatan kerja di bidang konstruksi bangunan adalah sebesar $20,07 \%$ sedangkan sisanya sebesar $79,93 \%$ dipengaruhi oleh faktor lain yang tidak dibahas dalam penelitian ini.

Dari perhitungan didapat persamaan regresi $Y$ atas $X$, yakni $Y=$ $83,226+7,455 \mathrm{X}$ hasil pengujian linieritas uji F diperoleh harga $F_{\text {hitung }}=0,81$. Se- lanjutnya, dikonsultasikan pada tabel distribusi $F$, dari tabel didapat harga $F_{(0,95)(83,7)}=3,42$. Ternyata $F_{\text {hitung }}<$ $F_{\text {tabel }}$, sehingga dapat disimpulkan bahwa regresi linier diterima pada tingkat kepercayaan 95\%.

Dari hasil penelitian, menunjukkan bahwa derajat hubungan antara hasil uji kompetensi siswa SMK Program Keahlian Gambar Bangunan terhadap kesempatan kerja di bidang konstruksi bangunan memiliki hubungan yang positif dan berarti dengan tingkat korelasi cukup, yang berarti bahwa hasil uji kompetensi siswa SMK Program Keahlian Gambar Bangunan memiliki pengaruh yang cukup terhadap kesempatan kerja di bidang konstruksi bangunan.

Tingkat hubungan yang cukup dan sumbangan sebesar 20,07\% dari hasil uji kompetensi siswa SMK Program Keahlian Gambar Bangunan terhadap kesempatan kerja di bidang konstruksi bangunan pada penelitian ini disebabkan oleh beberapa hal antara lain: adanya lulusan SMK Program Keahlian Gambar Bangunan yang mempunyai sertifikat uji kompetensi dan hasil uji kompetensi baik, bekerja tidak sesuai dengan kompetensi yang dimiliki hal ini dikarenakan kerja lebih berorientasi pada materi daripada minat dan bakat karena adanya persaingan dalam mendapatkan pekerjaan di industri konstruksi bagi lulusan SMK Bandung Program Keahlian Gambar Bangunan .

Untuk meningkatkan kesempatan kerja di bidang konstruksi bangunan tentunya harus memiliki sertifikat kompetensi dengan hasil uji kompeten- 
si yang baik, kompetensi yang dimiliki sesuai dengan kesempatan kerja di bidang konstruksi bangunan, pengumpulan data tentang kompetensi yang sesuai dengan kesempatan kerja di bidang konstruksi bangunan, serta penyempurnaan kurikulum yang benarbenar sesuai dengan tuntutan dunia kerja sehingga dapat mengisi kesempatan kerja di bidang konstruksi bangunan.

Dunia usaha dan dunia industri dalam bidang konstruksi sebagai Institusi pasangan dari SMK diharapkan memiliki komitmen, perhatian dan kesungguhan dalam proses menghasilkan tenaga kerja tingkat menengah. Untuk membangun komitemen dan kesungguhan tersebut diperlukan suatu kemitraan antara sekolah dengan dunia usaha dan dunia industri (DU/DI). Kemitraan sangat diperlukan dalam manajemen pembelajaran yang dibangun mulai dari pemahaman, sikap dan kontribusi dari dunia kerja-dunia industri terhadap sekolah dalam menghasilkan lulusan yang berorientasi sebagai tenaga kerja profesional pada tingkat menengah. Kemitraan seperti ini dapat dikatakan sebagai prilaku kemitraan antara kedua institusi dalam menghasilkan lulusan yang dikelola secara bersama dan tidak terbatas hanya sebagai tempat magang atau praktik industri bagi para peserta didik dari SMK. Sehingga peran kemitraan DUDI dalam sistem ganda dimulai dari penyusunan program sampai penilaian dan pengakuan hasil belajar dan penguasaan kompetensi dilakukan secara bersama. Peran DUDI juga sebagai sebagai quality control dalam penye- lenggaraan pendidikan menengah kejuruan. Peran tersebut berupa pemberian sertifikasi sebagai pengakuan berupa sertifikat kompetensi yang dikeluarkan oleh pihak industri/ lembaga sertifikasi profesi.

Kebijakan Sistem Ganda bertujuan untuk: (1) menghasilkan tenaga kerja yang bermutu yaitu tenaga kerja yang memiliki tingkat pengetahuan, keterampilan dan etos kerja yang sesuai dengan tuntutan lapangan pekerjaan; (2) memperkokoh keterkaitan dan kesepadananan antara SMK dan dunia kerja; (3) meningkatkan efektivitas proses pendidikan dan pelatihan tenaga kerja bermutu; (4) memberi pengakuan dan penghargaan terhadap pengalaman kerja sebagai bagian dari proses pendidikan.

Terdapat banyak komponen yang berperan dalam pendidikan sistem ganda dimana yang paling berperan langsung antara lain: pihak sekolah dan dunia industri/dunia usaha. Dengan demikian objek penelitian dalam penelitian ini adalah pihak sekolah mengenai Kemampuan Manajerial Kepala Sekolah dalam PSG, dan institusi pasangan sekolah yaitu dunia usaha atau dunia industri. Di sekolah terdapat pembelajaran yang menyiapkan siswa untuk memasuki dunia kerja, oleh karena itu pembelajaran pada program pemebelajaran pada pendidikan vokasi menurut Wermuth, dkk. (1997) "harus diarahkan pada kemampuan siswa untuk mengemban karir/pekerjaan.

Selain itu, pihak dunia industri mempunyai sistem atau iklim kerja sendiri yang sangat berbeda dengan iklim yang ada di sekolah, oleh karena 
itu sangat diperlukan kemitraan antara pihak sekolah dengan pihak dunia usaha atau dunia industri secara formal dan jelas sehingga terdapat relevansi apa yang dipelajari di sekolah dengan kenyataan di dunia kerja, Jeani Oakes, et.al (1992) menyebutnya sebagai "upaya matchmaking antara kemampuan akademik dan kemampuan vokasi".

\section{PENUTUP}

Uji kompetensi merupakan proses pengumpulan bukti-bukti dan membuat penilaian apakah suatu kompetensi telah tercapai, dan untuk mengetahui apakah siswa sudah dapat melaksanakan suatu pekerjaan yang telah ditetapkan sesuai dengan standar yang berlaku atau standar kompetensi yang ditetapkan.

Gambaran umum hasil uji kompetensi siswa SMK Bidang Keahlian Teknik Bangunan Program Keahlian Gambar Bangunan meliputi nilai uji kompetensi berada pada kategori baik, untuk aspek gambar teknik, menggambar bangunan, dan kompetensi menghitung rencana anggaran biaya konstruksi sederhana Hal ini menunjukkan bahwa tingkat kompetensi siswa program keahlian gambar bangunan pada umumnya tergolong baik. Uji kompetensi digunakan untuk melihat keberhasilan siswa berdasarkan ketentuan yanga ada pada kompetensi dan lebih mengutamakan kemampuan produktif. Secara teoretis dengan hasil uji kompetensi yang baik maka lulusan SMK Program Keahlian Gambar Bangunan dapat diterima dan memperoleh kesempatan kerja di bidang konstruksi bangunan.
Kesesuaian materi kompetensi dengan kesempatan kerja di bidang konstruksi bangunan. Dari hasil penelitian antara kesesuaian materi kompetensi dengan tugas pekerjaan di bidang konstruksi bangunan memiliki gambaran yang baik hal ini dapat diartikan bahwa kompetensi produktif Gambar Bangunan telah mendukung kesempatan siswa untuk bekerja di bidang konstruksi bangunan atau sebagai pelaksana tingkat menengah bidang konstruksi bangunan. Setiap isi atau materi kompetensi seperti gambar teknik, menggambar bangunan, dan kompetensi menghitung rencana anggaran biaya konstruksi sederhana dapat mendukung satu atau beberapa kemampuan dan tugas-tugas di bidang konstruksi bangunan, sehingga mereka bisa merebut kesempatan untuk bekerja di bidang konstruksi bangunan.

Hasil uji kompetensi siswa SMK Program Keahlian Gambar Bangunan memberikan pengaruh yang cukup bagi kesempatan kerja di bidang konstruksi bangunan, yang bisa diartikan bahwa siswa SMK Program Keahlian Gambar Bangunan yang telah memiliki sertifikasi uji kompetensi dengan hasil baik diprediksi akan dapat mempunyai kesempatan untuk bekerja di bidang konstruksi bangunan. Gambaran ini menunjukkan bahwa secara umum hasil uji kompetensi dapat dijadikan acuan untuk memprediksi kesempatan kerja yang akan diperoleh lulusan SMK, di luar faktor-faktor eksternal, seperti perkembangan pada sektor riil, kebijakan pemerintah, dan lain sebagainya. 
UCAPAN TERIMA KASIH

Ucapan terima kasih disampaikan kepada para siswa dan guru serta kepala SMKN 5 dan SMKN 6 di Kota Bandung yang telah memberikan izin, bantuan, dan kemudahan kepada peneliti mulai dari mendiskusikan permasalahan sampai pada pengumpulan data penelitian.

\section{DAFTAR PUSTKA}

Ainsworth, W James, and Vincent J Roscigno. 2005. "Stratification, School-Work Business and Vocational Education Social Forces", September 2005. 84, 1. ProQuest Education Journals, pg. 257.

Balley, Thomas R. 1977. Integrating Academic and Industry Skill Standards. NCRVE. http://vocserve.berkeley.edu/AllInOne $\mathbb{M}$ DS-1001.html.

Bunk, G. P. 1994. Teaching Competency in Initial and Continuing Vocational Training in the Federal Republic of Germany (CEDEFOP).

Butler, F.C. 1979. Instructional Systems Development for Vocational and Technical Training. Englewood Cliffs, N.J.: Educational Technology Publication.

Calhoun, C.C., Finch, A.V. 1982. Vocational Education: Concepts and Operations (2nd ed.). Belmont, California: Wadworth Publishing Company.
Descy P. Tessaring M. 2001. Training and Learning for Competency. Second Report on Vocational Training Research in Europe: Synthesis Report. (CEDEFOP).

Departemen Pendidikan dan Kebudayaan., 1993. Kumpulan Profil Kemampuan Tamatan dan Susunan Program Kurikulum Sekolah Menengah Kejuruan (SMK). Jakarta: Ditjen Dikdasmen, Dikmenjur.

Dougherty, Barbara; Ellibee, Margaret. 1995., Curriculum Quality Standards for School-to-Work: A Guidebook. NCRVE. http://Nocserve.berkeley.edu/AllInOneMDS955.html.

Finch, Curtis, R. Dan Crunkilton, R. J. 1979., Curriculum Development In Vocational Education. London: Ally and Balcon.

Meirawan, Danny. 1996. Keterkaitan dan Kepadanan Pengelolaan Program Pembelajaran di SMK Dengan Kebutuhan Dunia Industri. Disertasi, PPS IKIP Bandung.

Oakes, Jeanie.; et.al. 1992. Educational Matchmaking: Academic and Vocational Tracking in Comprehensive High Schools. NCRVE. http://vocserve.berkeley.edu/AllInOne/MD S-127.html.

Robinson, Joan. 1964., Pengantar Teori Kesempatan Kerja Employment. Jakarta : Bhratara. 
Stasz, Cathleen.; et.al. 1992. Classrooms That Work: Teaching Generic Skills in Academic and Vocational Settings. NCRVE. http:/Nocserve.berkeley.edu/AllInOne/MDS263.html.

Supratman, Yusuf. 1996. Kesesuaian Kurikulum Sekolah Teknik Menengah Program Studi Bangunan Gedung dengan Tuntutan Kerja. Tesis PPS IKIP Bandung: Tidak diterbitkan.
Wermuth, Thomas R.; et.al. 1997. Case Studies of Urban Schools: Portrayals of Schools in Change. NCRVE. http://vocserve.berkeley.edu/AlInOne MDS-958.html. 